\title{
JOBBERS AND THE EMERGENCE OF TRADE UNIONS IN BOMBAY CITY*
}

For the city of Bombay the establishment of British rule over Maharashtra (1818) inaugurated a period of extensive growth in trade, industry and banking. In search of wealth and power merchant communities and trading castes, mainly from the Northern province of Gujarat, settled in Bombay to exploit the economic opportunities that arose under the British raj. In the mid nineteenth century Indian entrepreneurs started a textile industry, which proved to be a new way to invest capital and to make profit. The management functions in their Bombay mills were filled by Europeans or Indians with an educated, middle-class background. The social and linguistic position of these people prevented their easy communication with the local labour-force of marathi-speaking peasant origin. Therefore, from the creation of the industry, mill-owners and management cadres delegated the task of labour recruitment to a special class of men, called jobbers.

These jobbers were both a pragmatic bridging of the social gap between mill management and labour, and the result of considerations of convenience as mill-owners were unwilling to invest into a regular system of personnel management. Coming from the rank and file, the jobbers were empowered to engage, to discipline and to dismiss workers and to give what elementary training was required. By this system of labour recruitment jobbers were able to wield considerable influence over labour. After the First World War, however, the jobbers had to face a new type of leadership, embodied in the emergent trade unions. The resulting confrontation between jobbers and tradeunion leaders as two different social groups with different techniques and styles of leadership took place under the impact of economic

* In a slightly different form this article was submitted as a paper to the Fifth European Conference on Modern Asian Studies, Leiden, 1976 (section Labour History). The author wishes to thank the Free University of Amsterdam for financial support to do research in India, and Professor Dr J. C. Heesterman (University of Leiden) for his useful comments on an earlier draft of the paper. 
crisis and growing government intervention in the period between the two world wars. ${ }^{1}$

\section{Jobber organisation of the Bombay textile labour-force}

The main qualification of a jobber was his ability to control a number of men. Industrial experience or knowledge of mechanical processes were of minor importance, as the level of technology was very low and the necessary skills could easily be acquired. In the beginning period or in later cases of labour scarcity the jobber might go to his home village to recruit labour that was needed in his department. But as a rule villagers in search of work migrated to the city and approached a jobber in order to secure industrial employment. Personal acquaintance and not technical skill proved to be the main factor in getting a job. The labourers recruited by the jobbers were mostly his kinsmen or came from the same village or caste, forging existing social relations into a new economic framework.

The jobber's position as foreman and supervisor enabled him to build up a position of considerable influence. Since he was entrusted with the distribution of eagerly sought employment opportunities labour looked up to him for jobs. The employment relationships may be said to have been set up between the jobbers and the labour-force rather than between the factory-management and labour. ${ }^{2}$ In that way every jobber had his own following, numbering about thirty or forty men. In larger establishments there even developed a hierarchy of jobbers, with head jobbers via their assistant jobbers controlling larger groups of labour. Far from being unorganised or chaotic, the textile labour-force was to its participants a well-organised universe of numerous jobber units. Every jobber unit was based on patronage and vertical loyalty, strengthened by kinship ties or common origin. The jobber guided fresh recruits in the difficult process of urban adjustment and advised them in accommodation and family affairs. As the mills used to keep the wages in arrears, most workers were short of money and it was the jobber who provided them with loans or stood security for them with professional money-lenders.

Labourers showed their allegiance to the jobber by rendering him

1 For a history of the Indian textile industry and its labour-force, see S. D. Mehta, The Indian Cotton Textile Industry: An Economic Analysis (Bombay, 1953); id., The Cotton Mills of India 1854-1954 (Bombay, 1954); M. D. Morris, The Emergence of an Industrial Labor Force in India: A Study of the Bombay Cotton Mills 1854-1947 (Berkeley, 1965); S. C. Jain, Personnel Management in India: Its Evolution and Present Status (Chapel Hill, 1968).

2 F. E. Hawkins, "The Selection and Supervision of Workpeople", in: Indian Textile Journal, XLIII (1932-33), p. 99. 
several services, the most conspicious being the payment of dasturi (commission). This payment of dasturi can be looked upon as exploitation and bribe, as often has been done, or as part and parcel of Indian traditional culture. Maybe there is also a reminder in it of the old system of reciprocity and redistribution in a closed community, as described by Neale. ${ }^{1}$ Personally I prefer the view that a jobber invested in men and that he tried to maximise not so much his financial profit as his network of personal relations with all the resources at his disposal.

The jobber functioned as a broker between management and labour. He acted as the spokesman for labour and as the protector of their interests, which were partly his own. For the mill managements the jobber formed the only communication channel with the workers, and for information about their labour-force they were almost completely dependent on him. Most of the early labour disputes centered round the jobber and the isolated and short-lived strikes before the 1920's coincided in their scope with a jobber's personal network. When a jobber conflicted with his management, not seldom from selfish motives, he could withdraw his men from the department concerned. When he was dismissed, most of the workers would follow him as they considered their fortunes to be tied to his. And in cases where he could not control labour unrest, the jobber often became the leader of a strike he could not prevent rather than lose his influence with the men.

The jobber may be called the de facto leader of the textile labourers. From his strategic position in a network of social relations he acted as a professional mediator in communication and distribution. We have to bear in mind, however, that the textile industry was only one sector of his multiple enterprise, although the most explicit one. Apart from being the leader of a labour-gang, he might run a teashop or liquor-shop, head a gymnasium, let rooms or have interests in ferries plying between Bombay and the coastal districts. In all these activities the jobber was investing in men, extending his personal control as far as possible. By overextension of his resources, personal conflicts or change of circumstances he might suffer in one field, but as his activities had many centres the jobber usually managed to survive.

1 W. C. Neale, "Reciprocity and Redistribution in the Indian Village: Sequel to Some Notable Discussions", in: Trade and Market in the Early Empires, ed. by K. Polanyi, C. M. Arensberg and H. W. Pearson (Glencoe, 1957), pp. 218-36. For another example, see H. Orenstein, "Gaon, the Changing Political System of a Maharashtrian Village", in: Change and Continuity in India's Villages, ed. by K. Ishwaran (New York, 1970), pp. 219-40. 
There were several conditions b...ich permitted the jobbersystem to flourish in the field of industry. These conditions were:

the loose organisation and inefficient use of labour within the mill, which permitted the jobber to recruit his own relatives or the best payers of dasturi, who were not necessarily the most suited to the job; the employers' indifference in matters of personnel management as long as labour discipline was maintained, the more so as the costs of selection fell back on labour itself (dasturi);

a high percentage of absenteism because of leave, sickness etc., which enabled the jobber to recruite temporary hands (badlis); by badli recruitment he could distribute his patronage on a larger scale and reap the fruits in the form of dasturi;

the lack of uniformity in wages and work rules, resulting in a high percentage of labour circulation between mills;

the delayed payment of wages, which, combined with a lack of cheap credit facilities, allowed the jobber to get a financial hold over his men; and the absence of an alternative mediator between employers and labour who could voice the workers' grievances and in case of conflict act as their leader.

As these conditions were shaped by historical circumstances, they were bound to change. In consequence, any change of these conditions would inevitably affect the jobber's position.

\section{New developments after World War I}

The trade union as a permanent and formal organisation to promote the cause of labour made its appearance on the industrial scene after the First World War. By including the elements "permanent", "formal" and "cause" in my definition I want to make a distinction between trade unions and earlier labour organisations or welfare associations. The World War, the Russian October Revolution and Gandhi's nonco-operation campaign provided strong incentives to the national movement in India. Political leaders, many of them with Communist leanings, began to realise that organised support from urban labour could be a valuable asset to their political struggle. Therefore, they turned to industrial workers in Bombay as well as elsewhere to broaden their political basis by the introduction of socio-economic issues. The moderate Bombay Textile Labour Union (1926) may be called the first genuine trade union in the Bombay textile industry, but it never attracted a large following. Increasingly, trade-union leaders of a Communist persuasion came to dominate the field, and in 1928 they established their own Girni Kamgar Union (GKU), absorbing some existing labour organisations. 
These more radical trade-union leaders were mostly Brahmins who laid claim to the political heritage of Tilak, the militant nationalist leader from Maharashtra. After Tilak's death (1920) Gandhi - whose home province was Gujarat - had risen to national prominence as his successor, giving the Indian National Congress a Gujarati colour and instilling it with a non-violent philosophy. In accordance with this course the local Congress organisation in Bombay, buttressed by industrial interests, refrained from lending support to textile strike movements. Some young Maharashtrian Brahmins, politically interested and assessing this situation, looked for a social basis but discovered a cause, labour, which they made their own. The tradition of militancy, inherited from Tilak, could be transferred to the labour movement and directed against the mainly Gujarati-speaking millowners and industrialists. Worried about the growing trade-union movement, some mill-owners once approached the local Congress leader Bhulubai Desai and asked him if he intended to support it. But they were set at ease by his reassuring remark: "I am not going to be father to someone else's child."'1

The GKU had its heyday after the 1928 strike, but lost most of its strength in the next year. After that the GKU slowly recovered and proved to be the driving force behind the general strike of 1934 . This major dispute caused the government to declare the GKU and its associated bodies unlawful organisations and to give permanent form to a trades-disputes conciliation machinery. These events may remind us of the fact that jobbers and trade-union leaders were not the only actors in the field. By industrial organisation and official legislation the Bombay Millowners Association (BMOA) and the government influenced and were part of the scenery on which jobbers and trade-union leaders met.

During and after the First World War the Bombay textile industry experienced a period of extensive growth and huge profits were made. But after 1922 the industrial boom petered out and from the mid 1920's onwards textiles suffered from a serious economic depression, the main causes being the worsening world market, the loss of the China trade in yarn, and increasing competition from the upcountry mills and especially from Japan. ${ }^{2}$ The mill-owners asked for government support, e.g., the abolition of an unfavourable excise duty, but their demands inaugurated a period of increasing government intervention in industrial affairs. In this, the government was

1 Interview with G. B. Mahashabde, who at that time was a journalist writing in favour of labour, Bombay, 9 November 1974.

${ }^{2}$ Report of the Indian Tariff Board (Cotton Textile Industry Enquiry) (Calcutta, 1927), Vol. I, p. 124. 
largely motivated by its concern for the maintenance of law and order, which were threatened by a growing labour unrest and supposed, widely feared Bolshevist influences. Official committees started their investigations into industrial efficiency and labour relations, resulting in recommendations which the mill-owners found hard to ignore.

In 1926 an official enquiry committee, the Indian Tariff Board, in its report recommended increased efficiency as "the true line of advance". As the jobber system did not guarantee efficient use of labour, the Board thought it to be desirable "that all labour should be engaged directly by the officer of the mill in charge of the department which requires it", i.c. manager or department master. ${ }^{1}$ In this recommendation the Board was supported by the evidence from several witnesses who exposed the jobbers as self-seeking exploiters of labour. To dislodge the jobbers from their entrenched position in the industry, however, the government needed co-operation of the mill-owners, which initially they were reluctant to give. As far as the jobbers were concerned, the mill-owners rejected a drastic reform of the existing system of labour management, as this might lead to labour troubles, endangering their already enfeebled industry. Therefore, direct recruitment, if introduced at all, came to mean a nominal transfer of power only, as management took responsibility for the selection made by the jobbers. The mill-owners and their managers were not afraid of the jobbers, who were in the last analysis their own employees, but took a strong dislike to the trade-union leaders, who were beyond their reach and could foment big strikes. By protecting their jobbers they hoped that these traditional leaders would hold back their men from joining a trade union.

At the same time the mill-owners professed preference to a course of increasing rationalisation of the production process to save their industry from ruin. In 1926 the Sassoon Agency introduced an efficiency scheme in its mills, spinners operating more spindles and weavers handling three instead of two looms. Other agencies followed suit. These programmes resulted in large-scale retrenchment: in the Sassoon mills alone 5,100 of the 27,000 hands were dismissed from service. ${ }^{2}$ From labourers working these schemes more skill and endurance were required. The mill-owners, however, took great care to leave the position of their head jobbers unimpaired. Head jobbers

1 Ibid., pp. 133, 138-139.

${ }^{2}$ Report of the Bombay Strike Enquiry Committee, 1928-1929 (Bombay, 1929) (hereafter Fawcett Committee), Vol. I, p. 159. It was Sir Victor Sassoon's deliberate policy to have "fewer, but more skilled and better-paid, operatives in Indian mills", S. Jackson, The Sassoons (London, 1968), pp. 214-15. 
were expressly kept out of the purview of Sassoon's efficiency scheme and the mill-owners standardisation scheme. ${ }^{1}$ By appeasing these most important jobbers they were expected to make the reforms acceptable to their labour clients. But this policy failed to avert the general strike of 1928, when widespread fear of unemployment and resistance to higher-output schemes led the workers to leave the mills in a body. After that, the Royal Commission on Labour (1929) observed a more critical note in the employers' treatment of the jobber issue. Representatives of the BMOA testified that the jobber was losing power and that labour was awakening. ${ }^{2}$ They now declared themselves to be in favour of curtailing the jobber's power, and in the 1930's the BMOA was more susceptible to government recommendations, although official pressure remained necessary.

Alarmed by the general strikes of 1928-29, the government passed legislation by which it could intervene in industrial disputes. A conciliatory machinery for the settlement of labour conflicts was developed by the institution of official Courts of Inquiry and Boards of Conciliation. ${ }^{3}$ The Royal Commission on Labour, stressing the evil effects of jobber-hiring practices, had pressed for the appointment of special labour officers to supervise recruitment. ${ }^{4}$ The Sassoon mills were the first to appoint their own mill labour officer, but only in 1933 and with restricted powers. ${ }^{5}$ In 1934 the Bombay government instituted a labour officer as part of its Trade Disputes Conciliation Bill. ${ }^{6}$ In Article 5 the duty of this officer was defined as "to watch the interests of workmen with a view to promote harmonious relations between employers and workmen and to take steps to represent the grievances of workmen to employers for the purpose of obtaining their redress". If negotiations proved fruitless, the government labour officer was authorised to refer a case to conciliation and could be appointed as a delegate on behalf of the workmen. In 1938 the submission of labour disputes to official arbitration was made compulsory by law.

Under some official pressure the BMOA appointed its own labour officer in the same year 1934. The Association's officer was instructed

1 Fawcett Committee. Vol. I, pp. 143, 165, 249. For standardisation, see below. 2 Royal Commission on Labour in India (hereafter Whitley Commission), Evidence (Calcutta, 1931), Vol. I, Pt 1, p. 386, and Pt 2, p. 320.

3 Trade Disputes Bill (1929), complete text in Labour Gazette (Bombay), VIII (1928-29), pp. 774-81.

Integrity, personality and linguistic facility were mentioned among the main qualities required for the post, see Whitley Commission, Report, pp. 24-25.

${ }_{5}$ This first labour officer was Mr C. A. Dalal, BA, BSc (London), who in a public lecture in September 1933 summarised his task as to take over the jobber's mediating role. Labour Gazette, XIII (1933-34), pp. 111-12.

- Complete text in Labour Gazette, XIV (1934-35), pp. 37-43. 
to co-operate with the government labour officer, to deal with corrupt jobbers and to inquire into abuses, especially the badli system. The jobber's control of badli labour was one of his main sources of strength. But his power in this field meant a loss both to the mill and to the substitute labourer in as much as the former lost efficiency by too large a turnover and the position of the latter remained highly uncertain. A radical solution of this problem was attained in the mid 1930 's, when the mill-owners' labour officer developed a badli control scheme. All the substitute hands in a mill were registered and the jobbers were compelled to fill their vacancies from registered badli card-holders, which drastically reduced their freedom of recruitment. ${ }^{1}$ In 1938 the BMOA instructed all member mills to engage labour officers to supervise recruitment, to deal with labour problems and to establish contact with the workforce. Nevertheless, in 1940 only 26 out of 68 working mills had appointed labour officers. ${ }^{2}$

From the mid 1920's onwards government officials and strike committees acting on behalf of labour urged more uniformity in wage structure and work rules. In 1928 the BMOA proposed a standardisation scheme which described in detail the different categories of work within the mill. After the 1928 strike it was amended by the Fawcett Enquiry Committee, ${ }^{3}$ but the employers lost interest and it was not implemented. Some progress was made in 1934, however, when under government pressure the BMOA adopted a scheme in which minimum wages were laid down for the same types of work. The Fawcett Committee also developed a new set of standing orders in consultation with representatives of mill-owners and labour. These orders included detailed prescriptions for leave, time of rest, payment of wages, etc., and defined breaches of discipline more clearly. Fines or dismissals, formerly a de facto prerogative of the jobber, were to be subjected to the signed approval of manager or department master. ${ }^{4}$

The appointment of labour officers created new channels of communication with the workforce. By introducing these official procedures of mediation and conciliation the government intended not only to prevent radical trade-union leaders from exploiting labour unrest for political ends, ${ }^{5}$ but also to replace or bypass the oldtime jobbers.

1 R. C. James, "Labor Mobility, Unemployment and Economic Change: An Indian Case", in: The Journal of Political Economy, LXVII (1959), pp. 551-52.

2 Report of the Textile Labour Inquiry Committee (Bombay, 1940), Vol. II, Final Report, p. 341.

3 Cf. p. 318 , note 2 .

4 Fawcett Committee, Vol. I, pp. 21-58, 180-87. On jobbers and fining as a disciplinary measure, see Labour Gazette, VI (1926-27), pp. 1103-24.

5 See, for instance, V. B. Karnik, Indian Trade Unions: A Survey (Bombay, 1960), p. 63. 
The formal regimentation of work rules (standing orders) was meant to protect the workers and to guarantee their employment, but at the same time it undermined the jobber's traditional hold on his men. The BMOA took the responsibility for the uniform application of these standing orders, which came into force in 1932. In actual practice, however, much was left to individual mill managements, which in many cases resented official tutelage and only paid lip-service to the reforms. As many management cadres had a soft corner in their hearts for the jobber, in some places his influence continued with the tacit approval of mill officials.

\section{The trade union: challenge and opportunity for the jobber}

The emergence of trade unions meant both a challenge and an opportunity for the jobber. At first sight, the modus operandi of a trade union is diametrically opposed to that of the jobbers, who were entrepreneurs in their own right. Their units were small, particularistic groups, held together by personal bonds of vertical loyality, whereas the emergent trade unions tried to organise labour on a much wider scale and to instill them with a feeling of horizontal solidarity based on a common economic position. But the modern educated and politically motivated trade-union leaders had to solve a crucial problem : how to overstep the limitations of the personal, particularistic small group toward the impersonal, administrative machinery of a regular organisation. In other words, they had to determine their position vis-à-vis the jobbers. Two ways could be followed: either fight the jobber by an active championing of labour interests with taking over his following as the final end in view, or use the jobber to attract membership with the risk that the trade-union movement became the sum total of several particularisms, combining only for short-term purposes. Both ways were tried, often simultaneously. The first course posed a new challenge to the jobbers, who at the same time had to face mounting pressure from economic reform and official legislation. The second course offered them an opportunity to extend their activities into the trade-union field. As their modus operandi was multi-centered, in this changing situation it was the trade union itself that could form another centre and a way to survive.

Before considering this dynamic interplay between trade-union leaders and jobbers in more detail, I must refer briefly to the Indian Trade Unions Act of 1926. This act conferred legal status on trade unions which met certain conditions, one being that "not less than one-half of the total number of the officers of every registered trade union shall be persons actually engaged or employed" in the industry 
concerned. ${ }^{1}$ As a result, labour organisations which were completely managed by well-meaning philanthropists without connections with the labour-force and with notepaper headings as their main evidence of reality were denied official registration, but jobber-led groups were not. The act stipulated that labour itself had to participate in the management of the union and allotted seats in executive bodies to workers, including the jobbers. The remaining seats could be filled by outsiders, including the "officious busy-bodies" who were much resented by the mill-owners, who feared they would introduce political controversies into industrial affairs. Nevertheless, Article 22 of this act may be said to have defined the formula for trade-union organisation in the 1920's and 1930's: the co-operative alliance between two different socio-economic groups, jobbers and outside leaders.

It would be wrong to conclude from the co-operation formula mentioned that all jobbers were willing to co-operate. Many jobbers resisted the organisational efforts of trade-union leaders as an intrusion upon what they considered to be their own field. Besides, the stress these outsiders laid upon things like health care or education created needs among labour which the jobbers were unable to meet. Last but not least, trade unions tended to place the jobbers on an equal footing with the rank and file and to take over their position of leadership and authority. These considerations might lead jobbers to fight the trade union with their hold on the men as their most obvious weapon. Either out of ignorance or by wilful misleading, they could encourage dormant suspicion among their men against the interference of educated, high-caste outsiders and sow distrust of those people's ulterior motives. If jobbers got wind of workers who did take part in trade-union activities, they could punish them by supplying bad material, inflicting fines at the slightest pretext or ultimately by dismissing them from service. In the 1920's the Bombay Textile Labour Union brought to light several cases of workers who were dismissed by their jobbers for the sole reason of being union members. ${ }^{2}$

It also happened that earlier involvement of jobbers in welfare associations paved the way for a transition and extension of their activities into the trade-union framework. Organisations like Kamgar Hitwardhak Sabha (1909) and Girni Kamgar Mahamandel (1923) were largely built up from the personal networks round a number of jobbers who combined forces to promote labour welfare and industrial peace. ${ }^{3}$

1 Article 22. Text of the act in Annual Report of the Bombay Millowners Association, 1927, pp. 372-80.

${ }^{2}$ Whitley Commission, Evidence, Vol. I, Pt 1, p. 299, and Pt 2, p. 257.

3 S. M. Rutnagur, Bombay Industries: The Cotton Mills (Bombay, 1927), pp. 485-86, 488; B. G. Meher, "Early Labour Movement in Bombay City 
In so far as any ideology prevailed, there was a vague non-Brahmin feeling, which was encouraged by leaders of a much wider nonBrahmin movement, who fought Brahmin dominance in all fields. I think this partly explains why the KHS and more emphatically the GKM debarred outsiders from membership of its managing committee. During the 1920's, however, threatened retrenchment and wage-cuts made the GKM realise that its real opponents were Gujarati mill-owners and not high-caste trade-union leaders. The Brahmin Communist Joglekar, who had gained influence in the GKM, contributed to this change of outlook. On the eve of the 1928 strike the GKM split, ${ }^{1}$ which shows two things. On the one hand, some GKM leaders could not see eye to eye with the new trade-union leaders and clinged to their jobber-led organisation. On the other hand, it is important that the main body passed into the GKU, which was formed and registered the same year with the Communist Dange as secretary. So, the development from early jobber-led welfare associations to new emerging trade unions can be seen as a continuity in change, with jobbers promoting their interests and those of their following within new organisational patterns.

There are several indications that in the course of the 1920's relations between the jobbers and workers became more strained. In 1929 officers of the Bombay Textile Labour Union testified, in accordance with the evidence from the BMOA quoted above, that the jobbers were losing control and that among labourers there were often two camps, one pro- and the other anti-jobber. ${ }^{2}$ The number of strikes in support of dismissed jobbers was lessening, and in the same year a mill-owner declared that things had "become topsy turvy last year when workers wanted some jobbers to be dismissed" and threatened to go on strike if their demand was not satisfied. ${ }^{3}$ With growing outside interference in labour relations workers apparently began to dissociate themselves from traditional bonds of loyalty. They became more inclined to follow the lead of radical trade unionists, who promised the fulfilment of the largest economic and

1875-1918" (Master thesis, Tata Institute of Social Sciences, Bombay, 1965), ch. VI; R. K. Newman, "Labour Organisation in the Bombay Cotton Mills, 1918-1929" (Ph.D. thesis, University of Sussex, 1970). The author is grateful to both Mr Meher and Dr Newman, who kindly permitted him to consult their unpublished theses.

1 Report of the Workers and Peasants Party of Bombay, signed by S. V. Ghate (n.d., the envelope is postmarked December 1928), Meerut Conspiracy Papers, National Archives of India, New Delhi; interview with Dr G. Adhikari, senior Communist leader, New Delhi, 3 December 1974.

2 Whitley Commission, Evidence, Vol. I, Pt 1, p. 298; cf. above, p. 319.

${ }^{3}$ H. P. Mody, chairman of the BMOA, ibid., Pt 2, p. 330; see also p. 263. 
social hopes. How strongly jobbers resented such tendencies we have already noticed in this chapter. But a jobber persisting in his opposition to the union ran the risk that his men would desert him, leaving him behind as a leader without a following and as a man who openly sided with the mill management. Moreover, in many cases financial dealings were part of the relationship between jobber and labour, which if broken might mean a substantial loss to the jobber. Therefore, many jobbers were dragged into the trade-union movement by their labour clients and were mainly motivated by the desire not to lose their remaining influence with the men. This course of events was partly a deliberate trade-union tactic. As one former GKU leader confided to me: "Winning their labourers over to our side was our main instrument in breaking the resistance of the jobbers." 1

The existence of socio-economic ties could produce the same result the other way round, workers following their jobber into the union. Some jobbers were popular with their men, others did not shrink from applying some coercion. Trade unions sometimes effected the dismissal of hostile labourers; this indicates - among other things the active influence of jobbers, who made use of victimisation to serve union purposes. ${ }^{2}$ A worker from the Swan mill told me that in the 1930's workers in his mill joined the GKU merely on the advice of their jobbers and out of fear of dismissal. ${ }^{3}$

It is true that the trade union deprived the jobber of much of his power. But on the other hand it offered him new opportunities. Perturbed by official attack and industrial reform, the jobber could use the union as a protective cover and a means to strike back, the more so as jobbers and trade unionists discovered in the labour officer their common enemy. In the union the jobber could find new ways to extend his relations and regain part of his lost influence. Very often it was jobbers who sat on mill committees or who were instrumental in organising demonstrations or protest meetings. As union fees replaced dasturi it was usually jobbers who were entrusted with the task of collecting subscriptions in their departments, money which they were supposed to hand over to the trade-union officials.

What's more, joining a trade union provided the jobber with an opportunity of upward mobility which he had never had before. Formerly the jobber had no prospect of further promotion, as his position was the highest attainable to labour and the ranks of middle management remained firmly closed to him. Now as trade-union members some jobbers were promoted to positions of leadership,

1 Interview with N. S. Desai, former GKU leader, Bombay, 20 November 1974.

2 See, for instance, Fawcett Committee, Vol. I, p. 61.

3 Interview with C. B. Patil, senior textile worker, Bombay, 20 November 1974. 
raising their social status in an unprecedented way: they shared platforms with educated outsiders, made speeches before mass gatherings and saw their names mentioned in the local press. Although only a few of them rose to such prominence, their example opened a new way to enhance personal influence and served as an incentive to other jobbers. Finally, some jobbers formed their own trade unions, giving impressive names to unions that were practically non-existent. In so far as these unions were alleged to be creations of the mill companies, it seems probable that these jobbers joined hands with their employers in launching a counter-offensive against the genuine trade unions. Their date of formation, during the 1929 strike, also points in this direction. As the examples I have averaged a membership of ten persons, it is clear that in this role the jobber performed badly. ${ }^{1}$

From this brief survey it can be concluded that there was not an uniform jobber response. Stubborn resistance and whole-hearted support to the trade-union movement were only extreme poles on a continuum of jobber attitudes with many variations in between. Although I tried to discern a rationale behind their attitudes, I do not think the jobbers were cool calculators who consciously and deliberately determined their course. They responded to changes in their own situation without understanding the greater developments that effected them. Whichever course they followed, they were primarily led by an instinctive desire to maintain their personal influence as much as possible. Therefore, one jobber could follow several courses, combining some at the same time.

\section{Trade unionists and jobbers}

The outside trade-union leaders possessed some very vital skills for the difficult task of organising labour unions. As a rule they were comparatively well educated and acquainted with the intricacies of administrative and legal procedures. These qualifications enabled them to run an organisational machinery that could surpass the limits of the small-scale jobber units. Their relatively high social status permitted them to approach the mill-owners in a more direct way when intervening in labour disputes and negotiating labour demands. As a chargehand the jobber always had to reckon with his employer, whereas the outside leaders, not being employed in the textile industry, enjoyed the advantages of an independent position. They could initiate actions or insist on demands without fear of intimidation or dismissal. By seizing upon the available channels of information and 1 Whitley Commission, Evidence, Vol. I, Pt 1, pp. 108, 354. 
publicity the outside leaders could attract the attention of a wider audience to the problems of labour. In local newspapers, at political meetings or before official committees of investigation they voiced and formulated workers' demands in the context of their own political views. Their intellectual frame of reference and comprehensive approach enabled them to look at textile problems from the perspective of long-term political and economic developments affecting their society and to appraise the need of industrial reform. Last but not least, they established friendly connections between their own unions and trade-union organisations abroad, which yielded them substantial financial assistance in continuing the 1928 general strike. ${ }^{1}$ In that way, the unions were able to give relief to the families of workers on strike, which the jobber never could do as strikes always meant loss of income and strike-funds were wanting.

These outstanding qualifications clearly distinguished the outside trade unionists from the ordinary jobbers, but they proved to be insufficient to win the workers' confidence and to establish a base of support among them. Although they descended to take sides with labour and devoted their time and energies to its cause, nonetheless these leaders could only narrow, not bridge, the social gap that divided them from the workers. They lacked personal connections with the men they wanted to serve. On entering the field of the textile industry, the outsiders discovered that power among labour was still largely vested in the jobbers, and that first and foremost they had to tackle the difficult problem of a deeply rooted jobber system.

There were several reasons why the outside trade-union leaders could not immediately dispense with the jobbers and even needed their co-operation. Although most of these outsiders regarded the jobber as the first enemy of labour and dasturi as sheer extortion, they had to accept him as a reality of the situation. Traditional bonds were loosening, but the jobber was still a force to be reckoned with. Therefore, the outside leaders tried to infiltrate existing jobberrun organisations such as the GKM, and to persuade the more amenable jobbers to join those unions in order to throw in their lot with the workers. As the jobbers still commanded a large following and many workers considered them their natural leaders, the traditional pattern of labour organisation could be used to serve union purposes. Closer co-operation with some jobbers also provided the outside leaders with the opportunity to establish a more personal rapport with the labourforce and to infuse the workers with their own ideas. As most of the trade-union leaders initially had only a faint notion of the inside 1 Newman, "Labour Organisation in the Bombay Cotton Mills", op. cit., pp. 196, 251, 278; Whitley Commission, Evidence, Vol. I, Pt 2, p. 271. 
working of the textile mills, the jobbers could supply them with the necessary technical information and explain the practical consequences of increased efficiency schemes. Most important of all, by appointing a jobber as union president - as was often the case - the trade union got a personal face, which facilitated the transition from the personal, particularistic group to the impersonal, administrative machinery.

Put briefly, the educated leaders accepted jobbers out of necessity and not out of love. In so far as jobbers whole-heartedly co-operated and completely identified themselves with labour, they were treated as genuine comrades and full-fledged union members. But many trade unionists never completely trusted their jobber converts, who were regarded as the weakest link in the organisational set-up. During the 1934 strike some prominent jobbers and influential workers were expelled from the joint strike committee. They were accused of opposing the strike from a desire to join hands with their employers again. ${ }^{1}$

\section{Jobbers and trade unionists: a mariage de raison}

The alliance between jobbers and outside leaders in the trade union can most aptly be described as a mariage de raison: by entering into an uneasy relationship both partners hoped to foster their own interests. Whether the partners changed character within this relationship or the mariage de raison turned into a mariage d'amour are intriguing questions, which will not be discussed here. On this place I want to stress that the formula mentioned implied a merger of two conflicting ways of operation. The jobber who worked and lived among labour maintained a wide set of relations with individual men, whereas the union tended to treat workers as a category and to deal exclusively with their economic interests $v i s-\grave{a}$-vis the mill-owners. A jobber could remain in touch with workers who were out of employment and in situations of industrial peace, whereas a trade union depended largely upon working hands who could pay subscriptions and upon strike activity as the main instrument to enrol a membership. A jobber could give employment or grant leave to one man, whereas the union negotiated at a higher level to safeguard employment opportunities or to formalise labour discipline in the industry as a whole. In short, the jobber's relations with his men were multipurpose, many-stranded and face-to-face, whereas the union's approach was specific and bureaucratic.

These different ways of operation, brought together in a single organisation, put severe restrictions on the union's capability to

1 Bombay Chronicle, 1, 2 and 4 June 1934. 
develop a sense of common purpose and collective action. The survival of jobber power presented the trade-union movement with a shaky foundation, on which it was hard to build strength. It also offers an additional, perhaps better and at any rate more specific explanation for the unsteady development of textile unions in Bombay before the Second World War than do the usual explanations based on labour migration, illiteracy or employers' obstruction. 